\title{
MODERN SYSTEMS FOR ASSESSING THE INFORMATIZATION OF COUNTRIES IN THE CONTEXT OF GLOBAL SUSTAINABLE DEVELOPMENT
}

\author{
Lesya Petkova', Michael Ryabokon ${ }^{2}$, Yuriy Vdovychenko³
}

\begin{abstract}
Information and communication theories became a major driver of the economic development of countries in a global world. Information component plays a key role in the building of competitive potential of countries and the development of international relations. At the national level, the development of innovative technologies enables the countries to take higher ranking positions by the level of progress of information and communication technologies. The assessment is carried out using a number of indicators, calculated with the respective index system and applied for analysis of problem areas in politics, as well as for monitoring of progress in the field of innovative technologies introduction. Although, this methodology does not take into consideration the indicators over time. Therefore, this paper aims to study the dynamics of networked readiness index as a factor of informatization of global economic development. The authors suggested a methodology to determine the level of informatization of global economic development based on cluster analysis of countries according to the indicators, included in NRI, which makes it possible to eliminate this defect. Methodology. The methodology of the paper is based on statistical data, forming the analytical database of the research findings and being studied using cluster analysis. The paper reviews a new indicator, which enables considering the informatization of global economic development in a comprehensive manner: in dynamics by a group of countries. Results. As a result of the author's study, it has been established that, according to the level of informatization of global economic development, the countries can be divided into three groups: the countries with sustainable level of informatization, the ones with moderate development and the countries, which are the most backward by the level of informatization. Moreover, the paper identifies the countries, which had no data for the period under review, or underwent a transition from one informatization level to another one. Practical implications. The presented results make it possible to consider informatization of the global economic development in a comprehensive manner: in dynamics by a group of countries. It enables identification of the countries with a sustainable level of informatization of global economic development. Value/originality. As a result of the study, it has been proved that it is more expedient to study the countries, which underwent a transition from one level of informatization to another one during the period under review. The prospects of further studies in the above-stated area are in the search for factors to enable the transition of countries to a higher level of informatization of global economic development.
\end{abstract}

Key words: networked readiness index, NRI, ICT, cluster analysis.

JEL Classification: C38, F62, M38, O30, R11

\section{Introduction}

In the modern world, information and communication technologies (ICT) are increasingly being adopted in diverse spheres of social life, changing these spheres and providing social and human development with new features, senses, and values. Information and communication technologies became the major driver of the economic development of any country in the modern global world, and information component plays the key role in the building of competitive potential of countries and development of international relations.

Science, technology, and innovations (STI) play the predominant role in the implementation of the goals of sustainable development. The European Commission

\footnotetext{
Corresponding author:

${ }^{1}$ Cherkasy State Technological University, Ukraine.

E-mail: 1 petkova@ukr.net

${ }^{2}$ Cherkasy State Technological University, Ukraine.

E-mail: aegladchenko@i.ua

${ }^{3}$ Cherkasy State Technological University, Ukraine.

E-mail: yurockv@gmail.com
} 
monitors and provides consulting support to the "New Agenda 2030" in the implementation of global policy for sustainable development. The paper determines that STI will become the primary tool for the realization of the agenda for global development as far as it is capable of enhancing the efficiency in economic and ecological components of development, and finding new more comfortable conditions to meet human needs, to extend human rights and opportunities for the future. Successful use of the innovative scientific and technological potential will require a shift of the focus to the problem of sustainable development and reorientation from customary transfer of technology towards the formation of innovative space; strengthening of partnership between the countries, having a different level of development, with attraction of all interesting parties, including private sector and individual initiatives; introduction of "walk the talk" - the highest level of coherence between the policies of the participants in order to eliminate defects, provide internal integration, and create opportunities to take advantage from innovative and technological breakthrough (European Commission, 2015).

Multiple studies demonstrate that there is a link between the development of ICT and economic prosperity. Large-scale deployment of high-speed communication and Internet technologies is a catalyst for ICT development. It produces a multiplier effect on other sectors of the national economy, facilitates the acceleration of technological progress and the growth of GDP. Thus, the development of ICT is one of the strategical steps towards modernization of the economy.

\section{Importance of ICT}

In a highly competitive economy, information and communication technologies determine the speed of response to the variable market environment. Reengineering in the information sphere facilitates the enhancement of overall economic system performance. Information infrastructure of the country has to provide an opportunity for the realization of intellectual potential in the form of innovations. The parameters, characterizing the innovative process, include access to information resources, the formation of information infrastructure, and training of personnel to work in conditions of the global information society. The experience of foreign countries shows that the formation of information infrastructure and access to information resources is one of the key factors that affect the creation and implementation of innovations in the economy. At the national level, the development of innovative technologies enables a country to take higher ranking positions by the level of information and communication technology development. The assessment is carried out using a number of indicators, calculated with the respective index system and applied for analysis of problem areas in politics, as well as for monitoring of progress in the field of innovative technologies introduction. A selection of the calculation methods primarily depends on priorities of statistical analysis.

\section{Indices of ICT assessment}

Diverse indices are used to assess the level of ICT, as follows:

1. ICT Development Index (IDI), which has been published annually since 2009, is a composite index that combines 11 indicators into one benchmark measure. It is used to monitor and compare developments in information and communication technology (ICT) between countries and over time (International Telecommunication Union, 2017).

2. The Web Index, which is designed and produced by the World Wide Web Foundation for measurement of the World Wide Web's contribution to social, economic, and political progress in countries across the world (World Wide Web Foundation, 2014).

3. Networked Readiness Index (NRI) - determines the propensity for countries towards harnessing the power of information and communication technologies (ICT). For the time being, NRI is defined for 139 countries based on 53 features (World Economic Forum, 2016).

4. The Knowledge Economy Index (KEI) is an aggregate index that represents the overall level of development of a country or region in the Knowledge Economy (World Bank, 2007).

5. E-Government Development Index (EGDI) presents the state of E-Government Development of the United Nations Member States. The EGDI is a composite measure of three important dimensions of e-government, namely: provision of online services, telecommunication connectivity, and human capacity (United Nations, 2018).

Among the above-stated indexes, IDI considers just 11 indicators, The Web Index is limited by the impact of the Internet, KEI is focused on the knowledge economy, EGDI is calculated once per two years. Therefore, further study is focused on the Networked Readiness Index.

\section{Networked Readiness Index}

Networked Readiness Index (NRI) is a composite indicator, characterizing the level of information and communication technologies progress in countries throughout the world. It has been developed in 2001. It has been issued by the World Economic Forum and international business school INSEAD since 2002 within the framework of the annual series of reports on the development of information society in countries throughout the world - The Global 


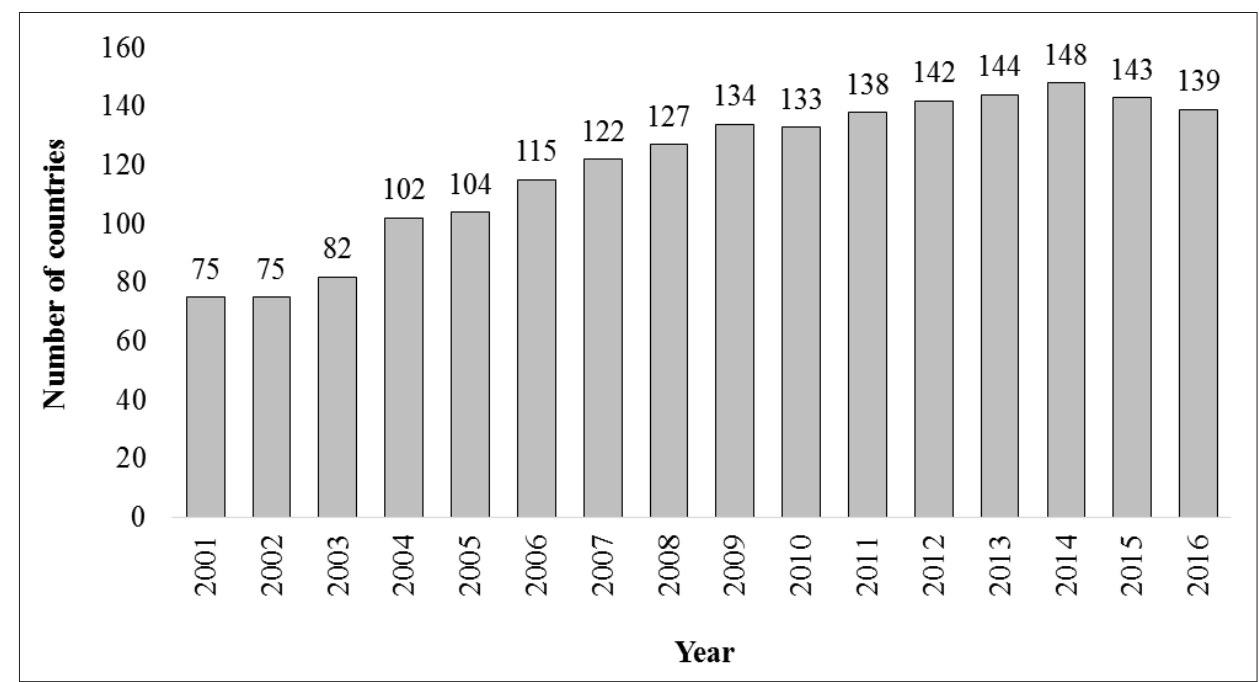

Figure 1. A number of countries, taken into consideration while calculating the Networked Readiness Index in 2001-2016

Source: World Economic Forum, 2002-2016

Information Technology Report. In 2013, Samuel Curtis Johnson Graduate School of Management joined the project. At present, the research is considered one of the most critical indicators of the country's potential and development opportunities. It is assumed that the index should be used by countries to analyse the most critical issues in their policy, as well as to monitor their progress in the area of introducing innovative technologies (WorldEconomicForum, 2002-2013). For the years of the report publication, a number of countries have been continuously changing (Figure 1). The approaches to assessment of NRI have been changing as well.

NRI is a globally accepted measure in determining the influence of ICT on an economy as a whole. Using a scale from one to seven, NRI is a composite indicator, made up of four main categories (subindexes), 10 subcategories (pillars), and 53 individual indicators distributed across the different pillars (Table 1). The four subindexes are (1) environment, (2) readiness, (3) usage, and (4) impact. NRI is included in the annual Global Information Technology Report, being published by INSEAD and the World Economic Forum (WEF) since 2001 (Tugas, 2016).

NRI helped policymakers and relevant stakeholders to track their economies' strengths and weaknesses, as well as their progress over time. However, the equalweight framework of the NRI methodology has been an issue of controversy. As a possible remedy to the issue, Milenkivic and al. presented the multilevel I-distance methodology. The I-distance approach can synthesize many indicators into one single numerical value that represents rank. With this approach, the entities can not only be ranked, but the differences between them are better explored (Milenkovic, Brajovic, Milenkovic, Vukmirovic, \& Jeremic, 2016). However, this methodology does not take into account the change of the indicators over time. This paper is aimed to study the dynamics of the networked readiness index as a factor of informatization of the world economic development. The authors suggested a methodology to determine the level of informatization of the global economic development based on cluster analysis of countries according to the indicators, included in NRI, which makes it possible to eliminate this defect.

\section{Cluster analysis of NRI factors}

The paper suggests grouping the countries in clusters by the criterion of similarity of NRI factors, as follows: A.01, A.02, B.03, B.04, B.05, C.06, C.07, C.08, D.09, D.10.

As far as all indicators are assessed on the scale from one to seven, in order to ensure comparability, the data for each indicator from Table 2.10 has been standardized using the following formula (Letser, 2018):

$$
\frac{x_{i}-\bar{x}}{s},
$$

where $x_{i}$ - the value of the indicator; $\bar{x}$ - mean value of the indicator; $\mathrm{n}$ - the number of indicators; $\mathrm{s}-$ standard deviation:

$$
s=\sqrt{\frac{\sum_{i=1}^{n}\left(x_{i}-\bar{x}\right)^{2}}{n-1}} .
$$

The missing data is defined as zero. Thus, the countries, where no data is submitted, are grouped in a separate cluster. The number of clusters was calculated using the method of k-means. Calculated results are shown in Figure 2.

As you can see in Figure 2, it is expedient to divide the countries into 4 clusters. Table 2 shows the results of cluster analysis across the indicators A.01, A.02, B.03, B.04, B.05, C.06, C.07, C.08, D.09, D.10. 
Vol. 5, No. 2, 2019

Table 1

The indicators, included in the Networked Readiness Index

\begin{tabular}{|c|c|c|}
\hline Series code & Series & Indicators in series \\
\hline A & \multicolumn{2}{|l|}{ Environment subindex } \\
\hline A.01 & $\begin{array}{l}\text { 1st pillar: Political and } \\
\text { regulatory environment }\end{array}$ & $\begin{array}{l}\text { Effectiveness of law-making bodies, laws relating to ICTs, judicial independence, efficiency } \\
\text { of legal system in settling disputes, efficiency of legal system in challenging regs, intellectual } \\
\text { property protection, software piracy rate, no. procedures to enforce a contract, no. days to } \\
\text { enforce a contract }\end{array}$ \\
\hline A.02 & $\begin{array}{l}\text { 2nd pillar: Business and } \\
\text { innovation environment }\end{array}$ & $\begin{array}{l}\text { Availability of the latest technologies, venture capital availability, total tax rate, no. days to start a } \\
\text { business, no. procedures to start a business, intensity of local competition, tertiary education gross } \\
\text { enrolment rate, quality of management schools, government procurement of advanced tech }\end{array}$ \\
\hline $\mathrm{B}$ & \multicolumn{2}{|l|}{ Readiness subindex } \\
\hline B.03 & 3rd pillar: Infrastructure & $\begin{array}{l}\text { Electricity production, mobile network coverage, int'l Internet bandwidth, secure Internet } \\
\text { servers }\end{array}$ \\
\hline B.04 & 4th pillar: Affordability & $\begin{array}{l}\text { Prepaid mobile cellular tariffs, fixed broadband Internet tariffs, Internet \& telephony } \\
\text { competition }\end{array}$ \\
\hline B.05 & 5th pillar: Skills & $\begin{array}{l}\text { Quality of educational system, quality of math \& science education, secondary education } \\
\text { gross enrolment rate, adult literacy rate }\end{array}$ \\
\hline $\mathrm{C}$ & \multicolumn{2}{|l|}{ Usage subindex } \\
\hline C.06 & 6th pillar: Individual usage & $\begin{array}{l}\text { Mobile phone subscriptions, individuals using Internet, households with personal computer, } \\
\text { households with Internet access, fixed broadband Internet, mobile broadband, use of virtual } \\
\text { social networks }\end{array}$ \\
\hline C.07 & 7th pillar: Business usage & $\begin{array}{l}\text { Firm-level technology absorption, capacity for innovation, PCT patents, ICT use for } \\
\text { business-to-business transactions, business-to-consumer Internet use, extent of staff training }\end{array}$ \\
\hline C.08 & 8th pillar: Government usage & $\begin{array}{l}\text { Importance of ICTs to gov't vision, government Online Service Index, Government success } \\
\text { in ICT promotion }\end{array}$ \\
\hline $\mathrm{D}$ & \multicolumn{2}{|l|}{ Impact subindex } \\
\hline D.09 & 9th pillar: Economic impacts & $\begin{array}{l}\text { Impact of ICTs on business models, ICT PCT patents, impact of ICTs on new organizational } \\
\text { models, knowledge-intensive jobs }\end{array}$ \\
\hline D. 10 & 10th pillar: Social impacts & $\begin{array}{l}\text { Impact of ICTs on access to basic services, Internet access in schools, ICT use \& government } \\
\text { efficiency, E-Participation Index }\end{array}$ \\
\hline
\end{tabular}

Source: World Economic Forum, 2016

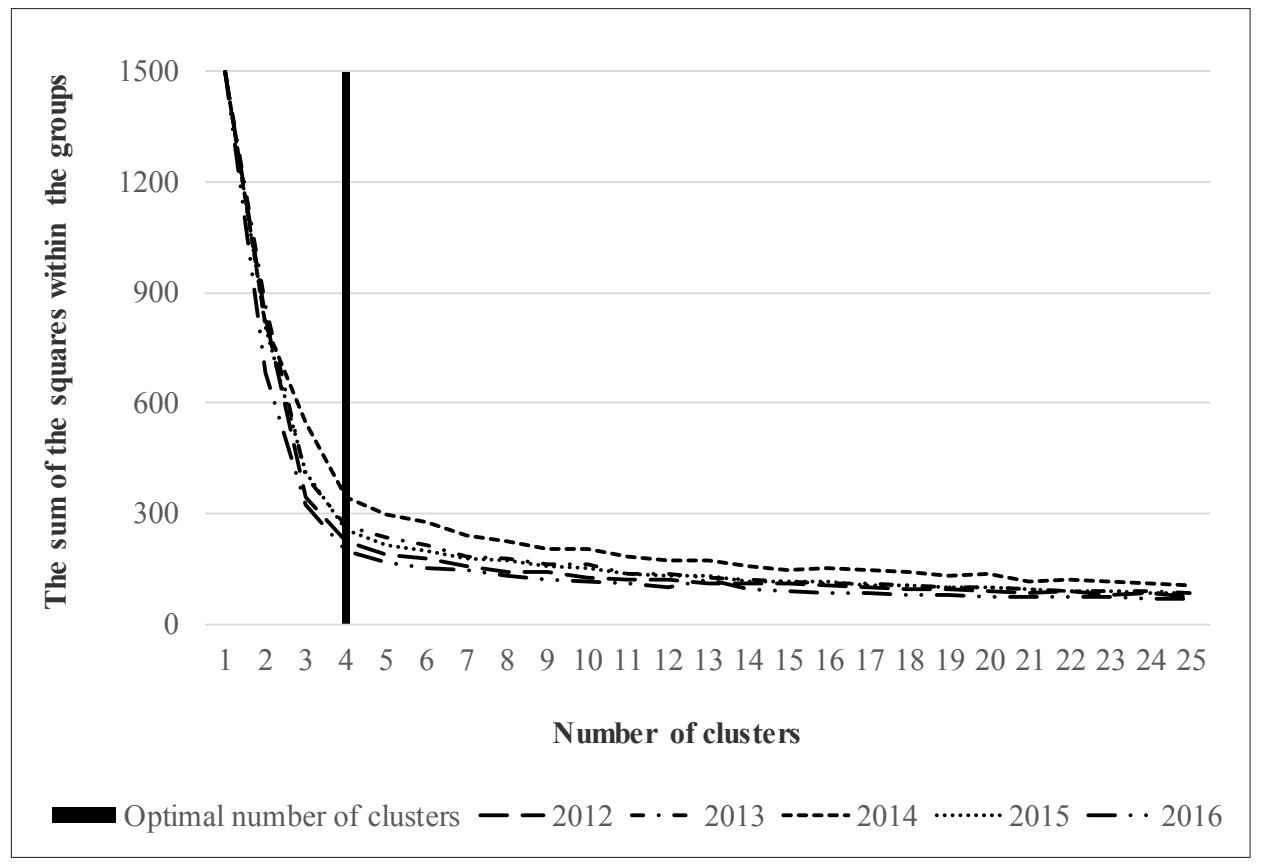

Figure 2. Calculation of the number of clusters for every year

Source: calculated by the authors according to the data of (World Economic Forum, 2016) 
Table 2

Results of cluster analysis for 2012-2016

\begin{tabular}{|c|c|c|c|c|c|}
\hline Country & 2012 & 2013 & 2014 & 2015 & 2016 \\
\hline AGO & 3 & 4 & 3 & 3 & 4 \\
\hline ALB & 2 & 2 & 2 & 2 & 3 \\
\hline ARE & 2 & 1 & 1 & 1 & 1 \\
\hline ARG & 2 & 2 & 3 & 3 & 3 \\
\hline ARM & 2 & 2 & 2 & 2 & 2 \\
\hline AUS & 1 & 1 & 1 & 1 & 1 \\
\hline AUT & 1 & 1 & 1 & 1 & 1 \\
\hline AZE & 2 & 2 & 2 & 2 & 2 \\
\hline BDI & 3 & 3 & 3 & 3 & 3 \\
\hline BEL & 1 & 1 & 1 & 1 & 1 \\
\hline BEN & 3 & 3 & 3 & 4 & 3 \\
\hline BFA & 3 & 3 & 3 & 3 & 4 \\
\hline BGD & 3 & 3 & 3 & 3 & 3 \\
\hline BGR & 2 & 2 & 2 & 2 & 2 \\
\hline BHR & 2 & 2 & 2 & 2 & 2 \\
\hline $\mathrm{BIH}$ & 2 & 2 & 2 & 4 & 3 \\
\hline BLZ & 3 & 4 & 4 & 4 & 4 \\
\hline $\mathrm{BOL}$ & 3 & 3 & 3 & 3 & 3 \\
\hline BRA & 2 & 2 & 2 & 2 & 2 \\
\hline BRB & 2 & 2 & 2 & 2 & 4 \\
\hline BRN & 2 & 3 & 2 & 4 & 4 \\
\hline BTN & 4 & 4 & 2 & 2 & 3 \\
\hline BWA & 3 & 3 & 3 & 3 & 3 \\
\hline CAN & 1 & 1 & 1 & 1 & 1 \\
\hline $\mathrm{CHE}$ & 1 & 1 & 1 & 1 & 1 \\
\hline $\mathrm{CHL}$ & 2 & 2 & 2 & 2 & 2 \\
\hline $\mathrm{CHN}$ & 2 & 2 & 2 & 2 & 2 \\
\hline CIV & 3 & 3 & 3 & 3 & 3 \\
\hline CMR & 3 & 3 & 3 & 3 & 3 \\
\hline $\mathrm{COL}$ & 2 & 2 & 2 & 2 & 2 \\
\hline $\mathrm{CPV}$ & 2 & 2 & 2 & 2 & 3 \\
\hline CRI & 2 & 2 & 2 & 2 & 2 \\
\hline CYP & 2 & 2 & 2 & 2 & 2 \\
\hline CZE & 2 & 2 & 2 & 2 & 2 \\
\hline DEU & 1 & 1 & 1 & 1 & 1 \\
\hline DNK & 1 & 1 & 1 & 1 & 1 \\
\hline DOM & 3 & 3 & 2 & 2 & 3 \\
\hline DZA & 3 & 3 & 3 & 2 & 3 \\
\hline ECU & 3 & 2 & 2 & 4 & 3 \\
\hline EGY & 2 & 3 & 2 & 2 & 3 \\
\hline ESP & 2 & 2 & 2 & 2 & 2 \\
\hline EST & 2 & 1 & 1 & 1 & 1 \\
\hline ETH & 3 & 3 & 3 & 3 & 3 \\
\hline FIN & 1 & 1 & 1 & 1 & 1 \\
\hline FRA & 1 & 1 & 1 & 1 & 1 \\
\hline GAB & 4 & 3 & 3 & 3 & 3 \\
\hline GBR & 1 & 1 & 1 & 1 & 1 \\
\hline GEO & 2 & 2 & 2 & 2 & 2 \\
\hline GHA & 3 & 3 & 2 & 3 & 3 \\
\hline GIN & 4 & 3 & 3 & 3 & 3 \\
\hline GMB & 3 & 3 & 3 & 3 & 3 \\
\hline GRC & 2 & 2 & 2 & 2 & 2 \\
\hline GTM & 3 & 3 & 3 & 3 & 3 \\
\hline GUY & 2 & 3 & 2 & 2 & 3 \\
\hline
\end{tabular}

\begin{tabular}{|l|c|c|c|c|c|}
\hline Country & 2012 & 2013 & 2014 & 2015 & 2016 \\
\hline
\end{tabular} \begin{tabular}{|l|l|l|l|l|l|}
\hline HKG & 1 & 1 & 1 & 1 & 1 \\
\hline HND & 3 & 3 & 3 & 2 & 3 \\
\hline
\end{tabular} \begin{tabular}{|l|l|l|l|l|l|}
\hline HRV & 2 & 2 & 2 & 2 & 2 \\
\hline
\end{tabular}

HTI \begin{tabular}{|l|l|l|l|l|l|}
\hline HUN & 2 & 2 & 2 & 2 & 2 \\
\hline
\end{tabular} \begin{tabular}{|l|l|l|l|l|l|}
\hline IDN & 2 & 2 & 2 & 2 & 3 \\
\hline
\end{tabular} \begin{tabular}{|l|l|l|l|l|l|}
\hline IND & 2 & 2 & 2 & 2 & 3 \\
\hline
\end{tabular} \begin{tabular}{|l|l|l|l|l|l|}
\hline IRL & 1 & 1 & 1 & 1 & 1 \\
\hline IRN & 3 & 3 & 3 & 2 & 3 \\
\hline
\end{tabular} \begin{tabular}{|l|l|l|l|l|l|}
\hline ISL & 1 & 1 & 1 & 1 & 1 \\
\hline
\end{tabular} \begin{tabular}{|l|l|l|l|l|l|}
\hline ISR & 1 & 1 & 1 & 1 & 1 \\
\hline
\end{tabular} \begin{tabular}{|l|l|l|l|l|l|}
\hline JAM & 2 & 2 & 2 & 2 & 2 \\
\hline JAM & 2 & 2 & 2 & 2 & 3 \\
\hline
\end{tabular} \begin{tabular}{|l|l|l|l|l|l|}
\hline JOR & 2 & 2 & 2 & 2 & 2 \\
\hline
\end{tabular} \begin{tabular}{|l|l|l|l|l|l|}
\hline JPN & 1 & 1 & 1 & 1 & 1 \\
\hline
\end{tabular} \begin{tabular}{|l|l|l|l|l|l|}
\hline KAZ & 2 & 2 & 2 & 2 & 2 \\
\hline
\end{tabular} \begin{tabular}{|l|l|l|l|l|l|}
\hline KEN & 3 & 3 & 2 & 2 & 3 \\
\hline KGZ & 3 & 3 & 3 & 2 & 3 \\
\hline
\end{tabular} \begin{tabular}{|l|l|l|l|l|l|}
\hline KHM & 3 & 3 & 3 & 3 & 3 \\
\hline
\end{tabular} \begin{tabular}{|l|l|l|l|l|l|}
\hline KOR & 1 & 1 & 1 & 1 & 1 \\
\hline KWT & 2 & 2 & 2 & 2 & 2 \\
\hline
\end{tabular} \begin{tabular}{|l|l|l|l|l|l|}
\hline KWT & 2 & 2 & 2 & 2 & 2 \\
\hline
\end{tabular} \begin{tabular}{|l|l|l|l|l|l|}
\hline $\mathrm{LAO}$ & 4 & 4 & 3 & 2 & 3 \\
\hline $\mathrm{LBN}$ & 2 & 2 & 3 & 2 & 2 \\
\hline
\end{tabular} \begin{tabular}{|l|l|l|l|l|l|}
\hline LBR & 4 & 3 & 3 & 4 & 3 \\
\hline
\end{tabular} \begin{tabular}{|l|l|l|l|l|l|}
\hline LBY & 4 & 3 & 3 & 2 & 4 \\
\hline
\end{tabular} \begin{tabular}{|l|l|l|l|l|l|}
\hline LKA & 2 & 2 & 2 & 2 & 2 \\
\hline
\end{tabular} \begin{tabular}{|l|l|l|l|l|l|}
\hline LSO & 3 & 3 & 3 & 3 & 3 \\
\hline LTU & 2 & 2 & 2 & 2 & 2 \\
\hline
\end{tabular} \begin{tabular}{|l|l|l|l|l|l|}
\hline LUX & 1 & 1 & 1 & 1 & 1 \\
\hline
\end{tabular} \begin{tabular}{|l|l|l|l|l|l|}
\hline LVA & 2 & 2 & 2 & 2 & 2 \\
\hline
\end{tabular} \begin{tabular}{|l|l|l|l|l|l|}
\hline MAR & 3 & 3 & 2 & 2 & 3 \\
\hline
\end{tabular} \begin{tabular}{|l|l|l|l|l|l|}
\hline MDA & 2 & 2 & 2 & 2 & 2 \\
\hline MDG & 3 & 3 & 3 & 3 & 3 \\
\hline
\end{tabular} \begin{tabular}{|l|l|l|l|l|l|}
\hline MEX & 2 & 2 & 2 & 2 & 3 \\
\hline
\end{tabular} \begin{tabular}{|l|l|l|l|l|l|}
\hline MKD & 2 & 2 & 2 & 2 & 2 \\
\hline
\end{tabular} \begin{tabular}{|l|l|l|l|l|l|}
\hline MLI & 3 & 3 & 3 & 3 & 3 \\
\hline MLT & 2 & 1 & 1 & 2 & 2 \\
\hline
\end{tabular} \begin{tabular}{|l|l|l|l|l|l|}
\hline MMR & 2 & 1 & 1 & 2 & 2 \\
\hline
\end{tabular} \begin{tabular}{|l|l|l|l|l|l|}
\hline MNE & 2 & 2 & 2 & 2 & 2 \\
\hline
\end{tabular} \begin{tabular}{|l|l|l|l|l|l|}
\hline MNG & 2 & 2 & 2 & 2 & 2 \\
\hline
\end{tabular} \begin{tabular}{|l|l|l|l|l|l|}
\hline MOZ & 3 & 3 & 3 & 3 & 3 \\
\hline MRT & 3 & 3 & 3 & 3 & 3 \\
\hline
\end{tabular} \begin{tabular}{|l|l|l|l|l|l|}
\hline MRT & 3 & 3 & 3 & 3 & 3 \\
\hline MUS & 2 & 2 & 2 & 2 & 2 \\
\hline
\end{tabular} \begin{tabular}{|l|l|l|l|l|l|}
\hline MWI & 3 & 3 & 3 & 3 & 3 \\
\hline
\end{tabular} \begin{tabular}{|l|l|l|l|l|l|}
\hline MYS & 2 & 2 & 2 & 2 & 2 \\
\hline
\end{tabular} \begin{tabular}{|l|l|l|l|l|l|}
\hline NAM & 3 & 3 & 3 & 3 & 3 \\
\hline
\end{tabular} \begin{tabular}{|l|l|l|l|l|l|}
\hline NGA & 3 & 3 & 3 & 3 & 3 \\
\hline
\end{tabular} \begin{tabular}{|l|l|l|l|l|l|}
\hline NIC & 3 & 3 & 3 & 3 & 3 \\
\hline
\end{tabular} \begin{tabular}{|l|l|l|l|l|l|}
\hline NLD & 1 & 1 & 1 & 1 & 1 \\
\hline
\end{tabular} \begin{tabular}{|l|l|l|l|l|l|}
\hline NOR & 1 & 1 & 1 & 1 & 1 \\
\hline NPL & 3 & 3 & 3 & 3 & 3 \\
\hline
\end{tabular} \begin{tabular}{|l|l|l|l|l|l|}
\hline NPL & 3 & 3 & 3 & 3 & 3 \\
\hline NZL & 1 & 1 & 1 & 1 & 1 \\
\hline
\end{tabular} \begin{tabular}{|l|l|l|l|l|l|}
\hline OMN & 2 & 2 & 2 & 2 & 2 \\
\hline PAK & 3 & 3 & 3 & 3 & 3 \\
\hline
\end{tabular} 


\begin{tabular}{|c|c|c|c|c|c|}
\hline Country & 2012 & 2013 & 2014 & 2015 & 2016 \\
\hline PAN & 2 & 2 & 2 & 2 & 2 \\
\hline PER & 3 & 3 & 2 & 2 & 3 \\
\hline PHL & 2 & 2 & 2 & 2 & 3 \\
\hline POL & 2 & 2 & 2 & 2 & 2 \\
\hline PRI & 2 & 3 & 2 & 2 & 4 \\
\hline PRT & 2 & 2 & 2 & 2 & 2 \\
\hline PRY & 3 & 3 & 3 & 2 & 3 \\
\hline QAT & 2 & 1 & 1 & 1 & 1 \\
\hline ROU & 2 & 2 & 2 & 2 & 2 \\
\hline RUS & 2 & 2 & 2 & 2 & 2 \\
\hline RWA & 3 & 3 & 3 & 3 & 3 \\
\hline SAU & 2 & 2 & 2 & 2 & 2 \\
\hline SEN & 3 & 3 & 3 & 3 & 3 \\
\hline SGP & 1 & 1 & 1 & 1 & 1 \\
\hline SLE & 4 & 3 & 3 & 4 & 4 \\
\hline SLV & 3 & 3 & 2 & 2 & 3 \\
\hline SRB & 2 & 2 & 2 & 2 & 2 \\
\hline SUR & 3 & 3 & 3 & 2 & 4 \\
\hline SVK & 2 & 2 & 2 & 2 & 2 \\
\hline SVN & 2 & 2 & 2 & 2 & 2 \\
\hline SWE & 1 & 1 & 1 & 1 & 1 \\
\hline SWZ & 3 & 3 & 3 & 3 & 3 \\
\hline SYC & 4 & 3 & 2 & 2 & 2 \\
\hline SYR & 3 & 4 & 4 & 4 & 4 \\
\hline TCD & 3 & 3 & 3 & 3 & 3 \\
\hline THA & 2 & 2 & 2 & 2 & 2 \\
\hline TJK & 3 & 3 & 4 & 3 & 3 \\
\hline TLS & 3 & 3 & 3 & 3 & 4 \\
\hline ТГО & 2 & 2 & 2 & 2 & 2 \\
\hline TUN & 2 & 4 & 2 & 2 & 3 \\
\hline TUR & 2 & 2 & 2 & 2 & 2 \\
\hline TWN & 1 & 1 & 1 & 1 & 1 \\
\hline TZA & 3 & 3 & 3 & 3 & 3 \\
\hline UGA & 3 & 3 & 3 & 3 & 3 \\
\hline UKR & 2 & 2 & 2 & 2 & 2 \\
\hline URY & 2 & 2 & 2 & 2 & 2 \\
\hline USA & 1 & 1 & 1 & 1 & 1 \\
\hline VEN & 3 & 3 & 3 & 2 & 3 \\
\hline VNM & 2 & 2 & 2 & 2 & 3 \\
\hline YEM & 3 & 3 & 3 & 3 & 4 \\
\hline ZAF & 3 & 3 & 3 & 2 & 2 \\
\hline ZMB & 3 & 3 & 3 & 3 & 3 \\
\hline ZWE & 3 & 3 & 3 & 3 & 3 \\
\hline
\end{tabular}

Source: calculated by the authors according to the data of (World Economic Forum, 2016)

Thus, according to the results of cluster analysis, for the period of 2012-2016 we can single out 4 clusters among 151 countries on the NRI factors: 1) countries with sustainable development;2) countries with moderate development of informatization; 3) countries, which are the most backward by the level of informatization; 4) countries with no data for the period under review. Table 3 shows the distribution of countries by clusters.
Table 3

Distribution of countries by clusters for the period of 2012-2016

\begin{tabular}{|c|c|c|c|c|}
\hline \multirow{2}{*}{ Year } & \multicolumn{3}{|c|}{ Cluster } & \multirow{2}{*}{ No data } \\
\cline { 2 - 5 } & 1 & 2 & 3 & 9 \\
\hline 2012 & 24 & 65 & 53 & 7 \\
\hline 2013 & 28 & 57 & 59 & 3 \\
\hline 2014 & 28 & 68 & 52 & 8 \\
\hline 2015 & 27 & 76 & 40 & 12 \\
\hline 2016 & 27 & 48 & 64 & \\
\hline
\end{tabular}

Source: calculated by the authors according to the data of (World Economic Forum, 2016)

Accordingly, Figure 3 shows the structure of informatization of the world economic development for the period of 2012-2016.

The analysis of countries' distribution by clusters for the period from 2012 to 2016 makes it possible to identify the following trends.

The first cluster includes the countries with sustainable development (24 countries): Australia, Austria, Belgium, Canada, Switzerland, Germany, Denmark, Finland, France, the United Kingdom, Hong Kong SAR, Ireland, Iceland, Israel, Japan, Rep. Korea, Luxembourg, Netherlands, Norway, New Zealand, Singapore, Sweden, Taiwan (China), and the United States.

The second cluster - the countries with moderate development of informatization (45 countries): Armenia, Azerbaijan, Bulgaria, Bahrain, Brazil, Barbados, Chile, China, Colombia, Costa Rica, Cyprus, Czech Republic, Georgia, Greece, Croatia, Hungary, Italy, Jordan, Kazakhstan, Kuwait, Spain, Sri Lanka, Lithuania, Latvia, Moldova, Macedonia FYR, Montenegro, Mongolia, Mauritius, Malaysia, Oman, Panama, Poland, Portugal, Romania, Russian Federation, Saudi Arabia, Serbia, Slovak Republic, Slovenia, Thailand, Trinidad and Tobago, Turkey, Ukraine, and Uruguay.

The third cluster is represented by the countries, which are the most backward by the level of informatization (43 countries): Angola, Burundi, Benin, Burkina Faso, Bangladesh, Belize, Bolivia, Botswana, Côte d'Ivoire, Cameroon, Chad, Ethiopia, Gabon, Guinea, The Gambia, Guatemala, Haiti, Cambodia, Liberia, Lesotho, Madagascar, Mali, Myanmar, Mozambique, Mauritania, Malawi, Namibia, Nigeria, Nicaragua, Nepal, Pakistan, Rwanda, Senegal, Sierra Leone, Swaziland, Syria, Tajikistan, Timor-Leste, Tanzania, Uganda, Yemen, Zambia, and Zimbabwe.

Besides the countries, which have been steadily related to a certain cluster for the period of 2012-2016, there are 39 countries, which had no data for the period under review, or underwent transition from one level of informatization to another one, i.e., moved from one cluster to another one (Table 4).

As you can see in Table 4, after 2012 the United Arab Emirates, Estonia, and Qatar moved to the first 


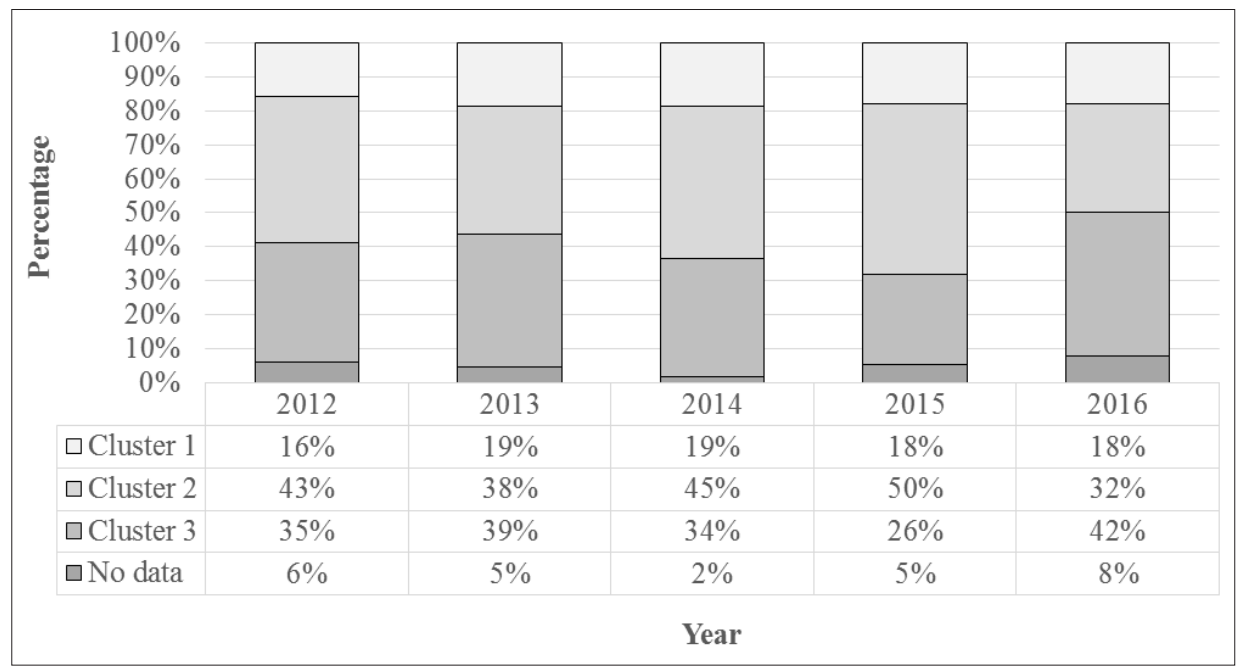

Figure 3. Structure of informatization of the world economic development for the period of 2012-2016

Source: calculated by the authors according to the data of (World Economic Forum, 2016)

Table 4

Clustering of the countries, which have an unstable level of informatization

\begin{tabular}{|c|c|c|c|c|c|c|}
\hline \multirow{2}{*}{ Country } & \multicolumn{5}{|c|}{ Year } & \multirow{2}{*}{ Averag } \\
\hline & 2012 & 2013 & 2014 & 2015 & 2016 & \\
\hline Albania & 2 & 2 & 2 & 2 & 3 & 2.2 \\
\hline Algeria & 3 & 3 & 3 & 2 & 3 & 2.8 \\
\hline Argentina & 2 & 2 & 3 & 3 & 3 & 2.6 \\
\hline Bhutan & - & - & 2 & 2 & 3 & 2.3 \\
\hline Bosnia and Herzegovina & 2 & 2 & 2 & - & 3 & 2.3 \\
\hline Brunei Darussalam & 2 & 3 & 2 & - & - & 2.3 \\
\hline Cape Verde & 2 & 2 & 2 & 2 & 3 & 2.2 \\
\hline Dominican Republic & 3 & 3 & 2 & 2 & 3 & 2.6 \\
\hline Ecuador & 3 & 2 & 2 & - & 3 & 2.5 \\
\hline Egypt & 2 & 3 & 2 & 2 & 3 & 2.4 \\
\hline El Salvador & 3 & 3 & 2 & 2 & 3 & 2.6 \\
\hline Estonia & 2 & 1 & 1 & 1 & 1 & 1.2 \\
\hline Ghana & 3 & 3 & 2 & 3 & 3 & 2.8 \\
\hline Guyana & 2 & 3 & 2 & 2 & 3 & 2.4 \\
\hline Honduras & 3 & 3 & 3 & 2 & 3 & 2.8 \\
\hline India & 2 & 2 & 2 & 2 & 3 & 2.2 \\
\hline Indonesia & 2 & 2 & 2 & 2 & 3 & 2.2 \\
\hline Islamic Rep. Iran & 3 & 3 & 3 & 2 & 3 & 2.8 \\
\hline Jamaica & 2 & 2 & 2 & 2 & 3 & 2,2 \\
\hline Kenya & 3 & 3 & 2 & 2 & 3 & 2.6 \\
\hline Kyrgyz Republic & 3 & 3 & 3 & 2 & 3 & 2.8 \\
\hline Lao PDR & - & - & 3 & 2 & 3 & 2.7 \\
\hline Lebanon & 2 & 2 & 3 & 2 & 2 & 2.2 \\
\hline Libya & - & 3 & 3 & 2 & - & 2.7 \\
\hline Malta & 2 & 1 & 1 & 2 & 2 & 1.6 \\
\hline Mexico & 2 & 2 & 2 & 2 & 3 & 2.2 \\
\hline Morocco & 3 & 3 & 2 & 2 & 3 & 2.6 \\
\hline Paraguay & 3 & 3 & 3 & 2 & 3 & 2.8 \\
\hline Peru & 3 & 3 & 2 & 2 & 3 & 2.6 \\
\hline Philippines & 2 & 2 & 2 & 2 & 3 & 2.2 \\
\hline Puerto Rico & 2 & 3 & 2 & 2 & - & 2.3 \\
\hline Qatar & 2 & 1 & 1 & 1 & 1 & 1.2 \\
\hline Seychelles & - & 3 & 2 & 2 & 2 & 2.3 \\
\hline
\end{tabular}




\begin{tabular}{|c|c|c|c|c|c|c|}
\hline \multicolumn{7}{|c|}{ (End of Table 4) } \\
\hline \multirow{2}{*}{ Country } & \multicolumn{5}{|c|}{ Year } & \multirow{2}{*}{ Average } \\
\hline & 2012 & 2013 & 2014 & 2015 & 2016 & \\
\hline South Africa & 3 & 3 & 3 & 2 & 2 & 2.6 \\
\hline Suriname & 3 & 3 & 3 & 2 & - & 2.8 \\
\hline Tunisia & 2 & - & 2 & 2 & 3 & 2.3 \\
\hline United Arab Emirates & 2 & 1 & 1 & 1 & 1 & 1.2 \\
\hline Venezuela & 3 & 3 & 3 & 2 & 3 & 2.8 \\
\hline Vietnam & 2 & 2 & 2 & 2 & 3 & 2.2 \\
\hline
\end{tabular}

Source: calculated by the authors according to the data of (World Economic Forum, 2016)

cluster. Malta also underwent such transition, but in 2015 this country returned to the second cluster. In 2014, Lebanon moved to the third cluster, but the next year this country returned to the second cluster. Ghana, on the contrary, in 2014 moved to the second cluster, but the next year this country returned to the third cluster. Four countries, namely, Dominican Republic, Kenya, Morocco, Peru and El Salvador, moved to the second cluster in 2014, where in 2015 six more countries joined them, as follows: Algeria, Honduras, Islamic Rep. Iran, Kyrgyz Republic, Paraguay, and Venezuela. However, in 2016, all ten countries returned to the third cluster. In 2016 eight countries moved to the third cluster, as follows: Albania, Cape Verde, Indonesia, India, Jamaica, Mexico, Philippines, and Vietnam, which were in the second cluster for the period of 2012-2015. Three countries, which in 2012 started from the second cluster, stayed in the third cluster at the end of the period under review: Argentina, Egypt, and Guyana. Only South Africa managed to move from the third cluster to the second one (in 2015) and not to return back. The following countries moved from one cluster to another one but, according to the latest available data, these countries are related to the third cluster: Bosnia and Herzegovina, Bhutan, Ecuador, Lao PDR, and Tunisia.

A calculation of the mean value by clusters for every country (Table 4) makes it possible to determine the average level of the country's informatization for the given period, as well as to provide visual results (Figure 4).

As you can see in Figure 4, the countries' distribution by the level of informatization makes it possible visually to assess the world economic development. Table 5 shows a change in the countries' rating for the whole period of NRI calculation.

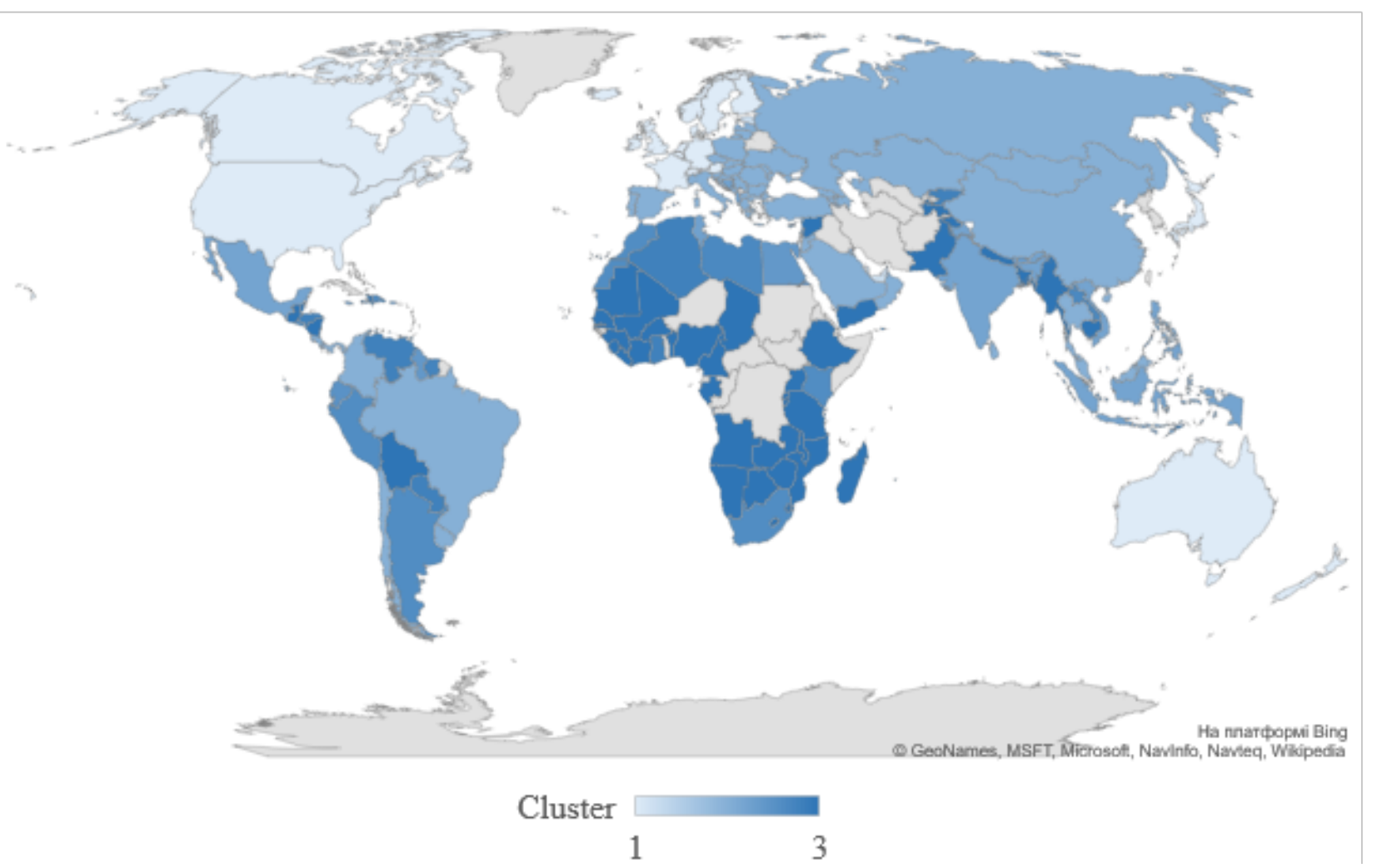

Figure 4. Clustering of the countries by the level of informatization of the world economic development in 2012-2016

Source: calculated by the authors according to the data of (World Economic Forum, 2016) 
Table 5

Change of the countries' rating according to NRI for the period of 2001-2016

\begin{tabular}{|c|c|c|c|c|c|c|c|c|c|c|c|c|c|c|c|c|c|}
\hline Country & ठ্ণ & రి & ஜి & ষ্ণ & 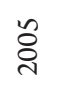 & ঃ & 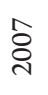 & $\stackrel{\infty}{\stackrel{\infty}{ి}}$ & ஓे & 옹 & $\vec{\nabla}$ & $\stackrel{\sim}{\stackrel{\sim}{\sim}}$ & $\stackrel{m}{\stackrel{d}{d}}$ & $\underset{\sim}{\stackrel{+}{\sim}}$ & $\stackrel{\sim}{\stackrel{\sim}{\sim}}$ & $\stackrel{0}{\stackrel{\sim}{\sim}}$ & 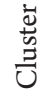 \\
\hline Singapore & 8 & 8 & 3 & 2 & 1 & 2 & 3 & 5 & 4 & 2 & 2 & 2 & 2 & 2 & 1 & 1 & 1 \\
\hline Finland & 3 & 3 & 1 & 3 & 3 & 5 & 4 & 6 & 6 & 6 & 3 & 3 & 1 & 1 & 2 & 2 & 1 \\
\hline Sweden & 4 & 4 & 4 & 4 & 6 & 8 & 2 & 2 & 2 & 1 & 1 & 1 & 3 & 3 & 3 & 3 & 1 \\
\hline Norway & 5 & 5 & 17 & 8 & 13 & 13 & 10 & 10 & 8 & 10 & 9 & 7 & 5 & 5 & 5 & 4 & 1 \\
\hline United States & 1 & 1 & 2 & 1 & 5 & 1 & 7 & 4 & 3 & 5 & 5 & 8 & 9 & 7 & 7 & 5 & 1 \\
\hline Netherlands & 6 & 6 & 11 & 13 & 16 & 12 & 6 & 7 & 9 & 9 & 11 & 6 & 4 & 4 & 4 & 6 & 1 \\
\hline Switzerland & 16 & 16 & 13 & 7 & 9 & 9 & 5 & 3 & 5 & 4 & 4 & 5 & 6 & 6 & 6 & 7 & 1 \\
\hline United Kingdom & 10 & 10 & 7 & 15 & 12 & 10 & 9 & 12 & 15 & 13 & 15 & 10 & 7 & 9 & 8 & 8 & 1 \\
\hline Luxembourg & & & 27 & 14 & 17 & 26 & 25 & 24 & 21 & 17 & 14 & 21 & 16 & 11 & 9 & 9 & 1 \\
\hline Japan & 21 & 21 & 20 & 12 & 8 & 16 & 14 & 19 & 17 & 21 & 19 & 18 & 21 & 16 & 10 & 10 & 1 \\
\hline Denmark & 7 & 7 & 8 & 5 & 4 & 3 & 1 & 1 & 1 & 3 & 7 & 4 & 8 & 13 & 15 & 11 & 1 \\
\hline Hong Kong SAR & 13 & 13 & 18 & 18 & 7 & 11 & 12 & 11 & 12 & 8 & 12 & 13 & 14 & 8 & 14 & 12 & 1 \\
\hline Rep. Korea & 20 & 20 & 14 & 20 & 24 & 14 & 19 & 9 & 11 & 15 & 10 & 12 & 11 & 10 & 12 & 13 & 1 \\
\hline Canada & 12 & 12 & 6 & 6 & 10 & 6 & 11 & 13 & 10 & 7 & 8 & 9 & 12 & 17 & 11 & 14 & 1 \\
\hline Germany & 17 & 17 & 10 & 11 & 14 & 17 & 16 & 16 & 20 & 14 & 13 & 16 & 13 & 12 & 13 & 15 & 1 \\
\hline Iceland & 2 & 2 & 5 & 10 & 2 & 4 & 8 & 8 & 7 & 12 & 16 & 15 & 17 & 19 & 19 & 16 & 1 \\
\hline New Zealand & 11 & 11 & 23 & 23 & 21 & 21 & 22 & 22 & 22 & 19 & 18 & 14 & 20 & 20 & 17 & 17 & 1 \\
\hline Australia & 14 & 14 & 15 & 9 & 11 & 15 & 15 & 14 & 14 & 16 & 17 & 17 & 18 & 18 & 16 & 18 & 1 \\
\hline Taiwan, China & 15 & 15 & 9 & 17 & 15 & 7 & 13 & 17 & 13 & 11 & 6 & 11 & 10 & 14 & 18 & 19 & 1 \\
\hline Austria & 9 & 9 & 16 & 21 & 19 & 18 & 17 & 15 & 16 & 20 & 21 & 19 & 19 & 22 & 20 & 20 & 1 \\
\hline Israel & 22 & 22 & 12 & 16 & 18 & 19 & 18 & 18 & 25 & 28 & 22 & 20 & 15 & 15 & 21 & 21 & 1 \\
\hline Belgium & 18 & 18 & 22 & 24 & 26 & 25 & 24 & 25 & 24 & 22 & 23 & 22 & 24 & 27 & 24 & 23 & 1 \\
\hline France & 24 & 24 & 19 & 19 & 20 & 22 & 23 & 21 & 19 & 18 & 20 & 23 & 26 & 25 & 26 & 24 & 1 \\
\hline Ireland & 19 & 19 & 21 & 22 & 22 & 20 & 21 & 23 & 23 & 24 & 29 & 25 & 27 & 26 & 25 & 25 & 1 \\
\hline Estonia & 23 & 23 & 24 & 25 & 25 & 23 & 20 & 20 & 18 & 25 & 26 & 24 & 22 & 21 & 22 & 22 & 1,2 \\
\hline United Arab Emirates & & & & & 23 & 28 & 29 & 29 & 27 & 23 & 24 & 30 & 25 & 24 & 23 & 26 & 1,2 \\
\hline Qatar & & & & & & 39 & 36 & 32 & 29 & 30 & 25 & 28 & 23 & 23 & 27 & 27 & 1,2 \\
\hline Malta & & & & 27 & 28 & 30 & 27 & 27 & 26 & 26 & 27 & 26 & 28 & 28 & 29 & 34 & 1,6 \\
\hline Bahrain & & & & & 33 & 49 & 50 & 45 & 37 & 29 & 30 & 27 & 29 & 29 & 30 & 28 & 2 \\
\hline Lithuania & 42 & 42 & 46 & 42 & 43 & 44 & 39 & 33 & 35 & 41 & 42 & 31 & 32 & 31 & 31 & 29 & 2 \\
\hline Portugal & 27 & 27 & 31 & 31 & 30 & 27 & 28 & 28 & 30 & 33 & 32 & 33 & 33 & 33 & 28 & 30 & 2 \\
\hline Malaysia & 36 & 36 & 32 & 26 & 27 & 24 & 26 & 26 & 28 & 27 & 28 & 29 & 30 & 30 & 32 & 31 & 2 \\
\hline Latvia & 39 & 39 & 38 & 35 & 56 & 51 & 42 & 44 & 48 & 52 & 52 & 41 & 41 & 39 & 33 & 32 & 2 \\
\hline Saudi Arabia & & & & & & & & 48 & 40 & 38 & 33 & 34 & 31 & 32 & 35 & 33 & 2 \\
\hline Spain & 26 & 26 & 25 & 29 & 29 & 31 & 32 & 31 & 34 & 34 & 37 & 38 & 38 & 34 & 34 & 35 & 2 \\
\hline Czech Republic & 28 & 28 & 28 & 33 & 40 & 32 & 34 & 36 & 32 & 36 & 40 & 42 & 42 & 42 & 43 & 36 & 2 \\
\hline Slovenia & 29 & 29 & 33 & 30 & 32 & 35 & 30 & 30 & 31 & 31 & 34 & 37 & 37 & 36 & 37 & 37 & 2 \\
\hline Chile & 34 & 34 & 35 & 32 & 35 & 29 & 31 & 34 & 39 & 40 & 39 & 39 & 34 & 35 & 38 & 38 & 2 \\
\hline Kazakhstan & & & & & & 60 & 73 & 71 & 73 & 68 & 67 & 55 & 43 & 38 & 40 & 39 & 2 \\
\hline Cyprus & & & & & 37 & 33 & 43 & 41 & 33 & 32 & 31 & 32 & 35 & 37 & 36 & 40 & 2 \\
\hline Russian Federation & 61 & 61 & 69 & 63 & 62 & 72 & 70 & 72 & 74 & 80 & 77 & 56 & 54 & 50 & 41 & 41 & 2 \\
\hline Poland & 35 & 35 & 39 & 47 & 72 & 53 & 58 & 62 & 69 & 65 & 62 & 49 & 49 & 54 & 50 & 42 & 2 \\
\hline Uruguay & 37 & 37 & 55 & 54 & 64 & 65 & 60 & 65 & 65 & 57 & 45 & 44 & 52 & 56 & 46 & 43 & 2 \\
\hline Costa Rica & 45 & 45 & 49 & 49 & 61 & 69 & 56 & 60 & 56 & 49 & 46 & 58 & 53 & 53 & 49 & 44 & 2 \\
\hline Italy & 25 & 25 & 26 & 28 & 45 & 42 & 38 & 42 & 45 & 48 & 51 & 48 & 50 & 58 & 55 & 45 & 2 \\
\hline Macedonia, FYR & & & & 75 & 85 & 82 & 81 & 83 & 79 & 73 & 72 & 66 & 67 & 57 & 47 & 46 & 2 \\
\hline Slovak Republic & 33 & 33 & 40 & 41 & 48 & 41 & 41 & 43 & 43 & 55 & 69 & 64 & 61 & 59 & 59 & 47 & 2 \\
\hline Turkey & 41 & 41 & 50 & 56 & 52 & 48 & 52 & 55 & 61 & 69 & 71 & 52 & 45 & 51 & 48 & 48 & 2 \\
\hline Mauritius & 51 & 51 & 56 & 43 & 47 & 45 & 51 & 54 & 51 & 53 & 47 & 53 & 55 & 48 & 45 & 49 & 2 \\
\hline Hungary & 30 & 30 & 30 & 36 & 38 & 38 & 33 & 37 & 41 & 46 & 49 & 43 & 44 & 47 & 53 & 50 & 2 \\
\hline Montenegro & & & & & 79 & 80 & 74 & & 71 & 42 & 44 & 46 & 48 & 52 & 56 & 51 & 2 \\
\hline Oman & & & & & & & & 53 & 50 & 50 & 41 & 40 & 40 & 40 & 42 & 52 & 2 \\
\hline Azerbaijan & & & & & & 73 & 71 & 67 & 60 & 64 & 70 & 61 & 56 & 49 & 57 & 53 & 2 \\
\hline
\end{tabular}


(Continuation of Table 5)

\begin{tabular}{|c|c|c|c|c|c|c|c|c|c|c|c|c|c|c|c|c|c|}
\hline Country & ఠ్రి & ఠิ & ஜे & ఫั & ஜิ & ఃे & ڤิ) & 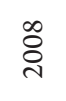 & ஓे & $\stackrel{\circ}{\circ}$ & $\overrightarrow{\text { సี }}$ & 곡 & $\stackrel{m}{\stackrel{n}{\pi}}$ & $\stackrel{+}{\stackrel{\lambda}{d}}$ & $\stackrel{\sim}{\check{i}}$ & $\stackrel{0}{\stackrel{1}{0}}$ & 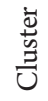 \\
\hline Croatia & & & 48 & 48 & 58 & 57 & 46 & 49 & 49 & 51 & 54 & 45 & 51 & 46 & 54 & 54 & 2 \\
\hline Panama & 48 & 48 & 61 & 58 & 69 & 66 & 65 & 64 & 66 & 58 & 60 & 57 & 46 & 43 & 51 & 55 & 2 \\
\hline Armenia & & & & & & 86 & 96 & 106 & 114 & 101 & 109 & 94 & 82 & 65 & 58 & 56 & 2 \\
\hline Mongolia & & & & & & 92 & 90 & 87 & 93 & 94 & 85 & 63 & 59 & 61 & 61 & 57 & 2 \\
\hline Georgia & & & & & 91 & 96 & 93 & 91 & 88 & 93 & 98 & 88 & 65 & 60 & 60 & 58 & 2 \\
\hline China & 64 & 64 & 43 & 51 & 41 & 50 & 59 & 57 & 46 & 37 & 36 & 51 & 58 & 62 & 62 & 59 & 2 \\
\hline Jordan & 49 & 49 & 51 & 46 & 44 & 47 & 57 & 47 & 44 & 44 & 50 & 47 & 47 & 44 & 52 & 60 & 2 \\
\hline Kuwait & & & & & & 46 & 54 & 52 & 57 & 76 & 75 & 62 & 62 & 72 & 72 & 61 & 2 \\
\hline Thailand & 43 & 43 & 41 & 38 & 36 & 34 & 37 & 40 & 47 & 47 & 59 & 77 & 74 & 67 & 67 & 62 & 2 \\
\hline Sri Lanka & 62 & 62 & 54 & 66 & 71 & 83 & 86 & 79 & 72 & 72 & 66 & 71 & 69 & 76 & 65 & 63 & 2 \\
\hline Ukraine & 66 & 66 & 70 & 78 & 82 & 76 & 75 & 70 & 62 & 82 & 90 & 75 & 73 & 81 & 71 & 64 & 2 \\
\hline Romania & 65 & 65 & 72 & 61 & 53 & 58 & 55 & 61 & 58 & 59 & 65 & 67 & 75 & 75 & 63 & 66 & 2 \\
\hline Trinidad and Tobago & 46 & 46 & 58 & 52 & 59 & 74 & 68 & 82 & 81 & 79 & 63 & 60 & 72 & 71 & 70 & 67 & 2 \\
\hline Colombia & 57 & 57 & 59 & 60 & 66 & 62 & 64 & 69 & 64 & 60 & 58 & 73 & 66 & 63 & 64 & 68 & 2 \\
\hline Bulgaria & 53 & 53 & 68 & 67 & 73 & 64 & 72 & 68 & 68 & 71 & 68 & 70 & 71 & 73 & 73 & 69 & 2 \\
\hline Greece & 31 & 31 & 42 & 34 & 42 & 43 & 48 & 56 & 55 & 56 & 64 & 59 & 64 & 74 & 66 & 70 & 2 \\
\hline Moldova & & & & & & 94 & 92 & 96 & 99 & & 97 & 78 & 77 & 77 & 68 & 71 & 2 \\
\hline Brazil & 38 & 38 & 29 & 39 & 46 & 52 & 53 & 59 & 59 & 61 & 56 & 65 & 60 & 69 & 84 & 72 & 2 \\
\hline Serbia & & & & 77 & 79 & 80 & 74 & & 84 & 84 & 93 & 85 & 87 & 80 & 77 & 75 & 2 \\
\hline Barbados & & & & & & & 40 & 38 & 36 & 35 & 38 & 35 & 39 & 55 & 39 & & 2 \\
\hline Indonesia & 59 & 59 & 64 & 73 & 51 & 68 & 62 & 76 & 83 & 67 & 53 & 80 & 76 & 64 & 79 & 73 & 2,2 \\
\hline Mexico & 44 & 44 & 47 & 44 & 60 & 55 & 49 & 58 & 67 & 78 & 78 & 76 & 63 & 79 & 69 & 76 & 2,2 \\
\hline Philippines & 58 & 58 & 62 & 69 & 67 & 70 & 69 & 81 & 85 & 85 & 86 & 86 & 86 & 78 & 76 & 77 & 2,2 \\
\hline Vietnam & 74 & 74 & 71 & 68 & 68 & 75 & 82 & 73 & 70 & 54 & 55 & 83 & 84 & 84 & 85 & 79 & 2,2 \\
\hline Jamaica & 56 & 56 & 60 & 53 & 49 & 54 & 45 & 46 & 53 & 66 & 73 & 74 & 85 & 86 & 82 & 83 & 2,2 \\
\hline Albania & & & & & & 106 & 107 & 108 & 105 & 95 & 87 & 68 & 83 & 95 & 92 & 84 & 2,2 \\
\hline Cape Verde & & & & & & & & & & & 84 & 81 & 81 & 89 & 87 & 85 & 2,2 \\
\hline Lebanon & & & & & & & & & & & 95 & 95 & 94 & 97 & 99 & 88 & 2,2 \\
\hline India & 54 & 54 & 37 & 45 & 39 & 40 & 44 & 50 & 54 & 43 & 48 & 69 & 68 & 83 & 89 & 91 & 2,2 \\
\hline Seychelles & & & & & & & & & & & & & 79 & 66 & 74 & 74 & 2,3 \\
\hline Tunisia & & & 34 & 40 & 31 & 36 & 35 & 35 & 38 & 39 & 35 & 50 & & 87 & 81 & 81 & 2,3 \\
\hline Bhutan & & & & & & & & & & & & & & 94 & 88 & 87 & 2,3 \\
\hline $\begin{array}{l}\text { Bosnia and } \\
\text { Herzegovina }\end{array}$ & & & & & 89 & 97 & 89 & 95 & 106 & 110 & 110 & 84 & 78 & 68 & & 97 & 2,3 \\
\hline Puerto Rico & & & & & & & & 39 & 42 & 45 & 43 & 36 & 36 & 41 & 44 & & 2,3 \\
\hline Brunei Darussalam & & & & & & & & & 63 & 63 & 57 & 54 & 57 & 45 & & & 2,3 \\
\hline Egypt & 60 & 60 & 65 & 65 & 57 & 63 & 77 & 63 & 76 & 70 & 74 & 79 & 80 & 91 & 94 & 96 & 2,4 \\
\hline Guyana & & & & & & 111 & 98 & 102 & 100 & 100 & 100 & 90 & 100 & 88 & 93 & 100 & 2,4 \\
\hline Ecuador & 71 & 71 & 75 & 89 & 95 & 107 & 97 & 107 & 116 & 114 & 108 & 96 & 91 & 82 & & 82 & 2,5 \\
\hline South Africa & 40 & 40 & 36 & 37 & 34 & 37 & 47 & 51 & 52 & 62 & 61 & 72 & 70 & 70 & 75 & 65 & 2,6 \\
\hline Morocco & & & 52 & 64 & 54 & 77 & 76 & 74 & 86 & 88 & 83 & 91 & 89 & 99 & 78 & 78 & 2,6 \\
\hline Kenya & & & & 84 & 75 & 91 & 95 & 92 & 97 & 90 & 81 & 93 & 92 & 92 & 86 & 86 & 2,6 \\
\hline Argentina & 32 & 32 & 45 & 50 & 76 & 71 & 63 & 77 & 87 & 91 & 96 & 92 & 99 & 100 & 91 & 89 & 2,6 \\
\hline Peru & 52 & 52 & 67 & 70 & 90 & 85 & 78 & 84 & 89 & 92 & 89 & 106 & 103 & 90 & 90 & 90 & 2,6 \\
\hline El Salvador & 55 & 55 & 63 & 62 & 70 & 59 & 61 & 66 & 78 & 81 & 92 & 103 & 93 & 98 & 80 & 93 & 2,6 \\
\hline Dominican Republic & 47 & 47 & 57 & 57 & 78 & 89 & 66 & 75 & 75 & 74 & 79 & 87 & 90 & 93 & 95 & 98 & 2,6 \\
\hline Lao PDR & & & & & & & & & & & & & & 109 & 97 & 104 & 2,7 \\
\hline Libya & & & & & & & & 105 & 101 & 103 & 126 & & 132 & 138 & 131 & & 2,7 \\
\hline Islamic Rep. Iran & & & & & & & & & & & 101 & 104 & 101 & 104 & 96 & 92 & 2,8 \\
\hline Honduras & 72 & 72 & 81 & 98 & 97 & 100 & 94 & 90 & 95 & 106 & 103 & 99 & 109 & 116 & 100 & 94 & 2,8 \\
\hline Kyrgyz Republic & & & & & & 103 & 105 & 114 & 115 & 123 & 116 & 115 & 118 & 118 & 98 & 95 & 2,8 \\
\hline Ghana & & & & 74 & 65 & 61 & & & 103 & 98 & 99 & 97 & 95 & 96 & 101 & 102 & 2,8 \\
\hline Paraguay & 63 & 63 & 76 & 91 & 98 & 113 & 114 & 120 & 122 & 127 & 127 & 111 & 104 & 102 & 105 & 105 & 2,8 \\
\hline Venezuela & 50 & 50 & 66 & 72 & 84 & 81 & 83 & 86 & 96 & 112 & 119 & 107 & 108 & 106 & 103 & 108 & 2,8 \\
\hline
\end{tabular}


(End of Table 5)

\begin{tabular}{|c|c|c|c|c|c|c|c|c|c|c|c|c|c|c|c|c|c|}
\hline Country & 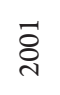 & ర్రి & ஓి & ষ্ণ & 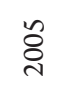 & ஓ্ণ & 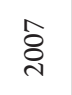 & $\stackrel{\infty}{\stackrel{\leftrightarrow}{\circ}}$ & ஓे & $\stackrel{\circ}{\stackrel{1}{0}}$ & $\overrightarrow{\text { D }}$ & $\stackrel{\sim}{\stackrel{\sim}{*}}$ & $\stackrel{m}{\stackrel{\sim}{\sim}}$ & $\underset{\sim}{\stackrel{+}{\circ}}$ & $\stackrel{\sim}{\stackrel{n}{\sim}}$ & $\begin{array}{l}0 \\
\stackrel{1}{\sim}\end{array}$ & 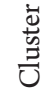 \\
\hline Algeria & & & & 87 & 80 & 87 & 80 & 88 & 108 & 113 & 117 & 118 & 131 & 129 & 120 & 117 & 2,8 \\
\hline Suriname & & & & & & & 110 & 117 & 117 & 126 & & 121 & 117 & 113 & 113 & & 2,8 \\
\hline Rwanda & & & & & & & & & & & & 82 & 88 & 85 & 83 & 80 & 3 \\
\hline Namibia & & & 53 & 59 & 55 & 78 & 85 & 93 & 92 & 89 & 82 & 105 & 111 & 105 & 102 & 99 & 3 \\
\hline Botswana & & & 44 & 55 & 50 & 56 & 67 & 78 & 77 & 86 & 91 & 89 & 96 & 103 & 104 & 101 & 3 \\
\hline Guatemala & 68 & 68 & 73 & 86 & 88 & 98 & 79 & 80 & 82 & 83 & 94 & 98 & 102 & 101 & 107 & 103 & 3 \\
\hline Côte d'Ivoire & & & & & & & & & 111 & 104 & 113 & 122 & 120 & 122 & 115 & 106 & 3 \\
\hline Senegal & & & & 81 & & & & 85 & 80 & 75 & 80 & 100 & 107 & 114 & 106 & 107 & 3 \\
\hline Cambodia & & & & & & 104 & 106 & 115 & 126 & 117 & 111 & 108 & 106 & 108 & 110 & 109 & 3 \\
\hline Pakistan & & & & 76 & 63 & 67 & 84 & 89 & 98 & 87 & 88 & 102 & 105 & 111 & 112 & 110 & 3 \\
\hline Bolivia & 67 & 67 & 78 & 90 & 99 & 109 & 104 & 111 & 128 & 131 & 135 & 127 & 119 & 120 & 111 & 111 & 3 \\
\hline Bangladesh & 73 & 73 & 77 & 93 & 100 & 110 & 118 & 124 & 130 & 118 & 115 & 113 & 114 & 119 & 109 & 112 & 3 \\
\hline The Gambia & & & & 82 & 74 & 88 & & 101 & 91 & 77 & 76 & 101 & 98 & 107 & 108 & 113 & 3 \\
\hline Tajikistan & & & & & & 93 & & 98 & 104 & 109 & 112 & 114 & 112 & & 117 & 114 & 3 \\
\hline Lesotho & & & & & & & 116 & 122 & 118 & 107 & 121 & 133 & 138 & 133 & 124 & 115 & 3 \\
\hline Zambia & & & & 85 & 81 & & 112 & 112 & 102 & 97 & 102 & 109 & 115 & 110 & 114 & 116 & 3 \\
\hline Nepal & & & & & & & 108 & 119 & 127 & 124 & 131 & 128 & 126 & 123 & 118 & 118 & 3 \\
\hline Nigeria & 75 & 75 & 74 & 79 & 86 & 90 & 88 & 94 & 90 & 99 & 104 & 112 & 113 & 112 & 119 & 119 & 3 \\
\hline Ethiopia & & & & 101 & 102 & 115 & 119 & 123 & 129 & 122 & 123 & 130 & 128 & 130 & 130 & 120 & 3 \\
\hline Uganda & & & & 80 & 77 & 79 & 100 & 109 & 120 & 115 & 107 & 110 & 110 & 115 & 116 & 121 & 3 \\
\hline Zimbabwe & 70 & 70 & 80 & 95 & 94 & 105 & 117 & 125 & 132 & 132 & 132 & 124 & 116 & 117 & 121 & 122 & 3 \\
\hline Mozambique & & & & 97 & 96 & 101 & 115 & 121 & 124 & 116 & 106 & 120 & 133 & 137 & 129 & 123 & 3 \\
\hline Cameroon & & & & 83 & & 99 & 113 & 118 & 123 & 128 & 125 & 125 & 124 & 131 & 126 & 124 & 3 \\
\hline Gabon & & & & & & & & & & & & & 121 & 128 & 122 & 125 & 3 \\
\hline Tanzania & & & & 71 & 83 & 84 & 91 & 100 & 119 & 120 & 118 & 123 & 127 & 125 & 123 & 126 & 3 \\
\hline Mali & & & & 96 & 92 & 95 & 101 & 99 & 107 & 96 & 120 & 126 & 122 & 127 & 127 & 127 & 3 \\
\hline Benin & & & & & & 108 & 109 & 113 & 121 & 111 & 114 & 117 & 123 & 135 & & 128 & 3 \\
\hline Swaziland & & & & & & & & & & & 134 & 136 & 136 & 126 & 125 & 129 & 3 \\
\hline Liberia & & & & & & & & & & & & & 97 & 121 & & 130 & 3 \\
\hline Nicaragua & 69 & 69 & 79 & 94 & 103 & 112 & 103 & 116 & 125 & 125 & 128 & 131 & 125 & 124 & 128 & 131 & 3 \\
\hline Malawi & & & & 88 & 93 & & 111 & & 110 & 119 & 105 & 116 & 129 & 132 & 133 & 132 & 3 \\
\hline Myanmar & & & & & & & & & & & & & & 146 & 139 & 133 & 3 \\
\hline Guinea & & & & & & & & & & & & & 140 & 145 & 142 & 134 & 3 \\
\hline Madagascar & & & & 92 & 87 & 102 & 102 & 104 & 112 & 121 & 129 & 134 & 137 & 139 & 135 & 135 & 3 \\
\hline Mauritania & & & & & & & 87 & 97 & 109 & 102 & 130 & 139 & 135 & 142 & 138 & 136 & 3 \\
\hline Haiti & & & 82 & 100 & & & & & & & & 142 & 141 & 143 & 137 & 137 & 3 \\
\hline Burundi & & & & & & & 121 & 126 & 131 & 129 & 137 & 137 & 144 & 147 & 141 & 138 & 3 \\
\hline Chad & & & & 102 & 104 & 114 & 122 & 127 & 134 & 133 & 138 & 138 & 142 & 148 & 143 & 139 & 3 \\
\hline Burkina Faso & & & & & & & 99 & 103 & 113 & 108 & 122 & 135 & 130 & 136 & 132 & & 3 \\
\hline Timor-Leste & & & & & & & & & 133 & 130 & 136 & 132 & 134 & 141 & 134 & & 3 \\
\hline Yemen & & & & & & & & & & & & 141 & 139 & 140 & 136 & & 3 \\
\hline Angola & & & & 99 & 101 & & 120 & & & & 133 & 140 & & 144 & 140 & & 3 \\
\hline Sierra Leone & & & & & & & & & & & & & 143 & 134 & & & 3 \\
\hline Belize & & & & & & & & & & & & 119 & & & & & 3 \\
\hline Syria & & & & & & & & 110 & 94 & 105 & 124 & 129 & & & & & 3 \\
\hline
\end{tabular}

Source: calculated by the authors according to the data of (World Economic Forum, 2002-2016) (World Economic Forum, 2002) (World Economic Forum, 2003) (World Economic Forum, 2004) (World Economic Forum, 2005) (World Economic Forum, 2006) (World Economic Forum, 2007) (World Economic Forum, 2008) (World Economic Forum, 2009) (World Economic Forum, 2010) (World Economic Forum, 2011) (World Economic Forum, 2012) (World Economic Forum, 2013) (World Economic Forum, 2014) (World Economic Forum, 2015) (World Economic Forum, 2016)

As you can see in Table 5, the average level of the country's informatization to a certain extent corresponds to the dynamics of rating according to NRI.
Thus, clustering of countries according to the indicators, being the basis of NRI, enables us to take dynamics into consideration and single out similar groups of countries. 


\section{Conclusions}

Therefore, based on the analysis of publicly available data, it has been established that the countries can be divided into three groups by the level of informatization of the world economic development. The first level - the countries with sustainable development. For the period of 2012-2016, 24 countries were steadily related to this cluster, plus the United Arab Emirates, Estonia, and Qatar, which joined them in 2013. These are the first 27 countries of NRI rating. The second level - the countries with moderate informatization development. For the period of 2012-2016, it steadily included 45 countries. Besides, still in 2014 Malta moved to the first level but it's already in 2015 that this country returned to the second level. There also were 17 countries, which left the group during the period of 2012-2016 and thereafter returned to it or moved to the third level. Now 63 countries are related to the second level of informatization. The third level - the countries, which are the most backward by the level of informatization. It is 43 countries, which are steadily related to the third level, and 18 countries, which were related to the second level in the period of 2012-2016. Totally we have reviewed 151 countries.

Before 2012, the countries' rating by NRI covers the period from 2001 to 2011. However, due to the advancement of the methodology for calculation of the Networked Readiness Index over the above-stated period and larger dispersion of countries' coverage than for the last years, it is not expedient to determine the level of informatization of the world economic development in such a way.

The results presented enable us to approach informatization of the world economic development comprehensively: in dynamics by groups of countries. It allows singling out the countries with the sustainable level of informatization of the world economic development. Although, it is more expedient to study the countries, which moved from one level to another one during the period under review. Perspectives of further studies in the above-stated direction consist in search of the factors, which enable the countries' transition to the higher level of informatization of the world economic development.

\section{References:}

European Commission (2015). The Role of Science, Technology and Innovation Policies to Foster the Implementation of the Sustainable Development Goals (SDGs). Report of the Expert Group "Follow-up to Rio+20, notably the SDGs". Retrieved October 31, 2018, from European Commission: http://ec.europa.eu/newsroom/horizon2020/ document.cfm?doc_id=12065

International Telecommunication Union (2017). ICT facts and figures 2017 . Retrieved from International Telecommunication Union: https://www.itu.int/en/ITU-D/Statistics/Documents/facts/ ICTFactsFigures2017.pdf

International Telecommunication Union (2017). The ICT Development Index (IDI): conceptual framework and methodology. Retrieved from International Telecommunication Union: https://www.itu.int/en/ITU-D/Statistics/ Pages/publications/mis2017/methodology.aspx

Letser, Y. O. (2018). Formuvannia kompleksnoi ekonomiko-orhanizatsiinoi modeli pidpryiemstv z rozrobky informatsiinykh tekhnolohii. Master's thesis. Rivne, Ukraine: NUVHP.

Milenkovic, M. J., Brajovic, B., Milenkovic, D., Vukmirovic, D. \& Jeremic, V. (2016). Beyond the equal-weight framework of the Networked Readiness Index: a multilevel I-distance methodology. Information Development, 32(4), 1120-1136.

Tamilselvan, N., Sivakumar, N. \& Sevukan, R. (2012). Information and communications technologies (ICT). International Journal of Library and Information Science (IJLIS), 1(1), 15-28.

Tugas, F. C. (2016, May). Clues from networked readiness index: business imperatives and challenges. DLSU Business notes and briefings, 4(4), 1-6.

United Nations (2018). E-Government Development Index (EGDI). Retrieved from UN E-Government Knowledgebase: https://publicadministration.un.org/egovkb/en-us/About/Overview/-E-Government

World Bank (2007). Knowledge Economy Index (KEI) 2007 Rankings. Retrieved from The World Bank: https://siteresources.worldbank.org/KFDLP/Resources/461197-1170257103854/KEI.pdf

World Economic Forum (2002). The Global Information Technology Report 2001-2002. Readiness for the Networked World. Retrieved October 30, 2018, from United Nations: http://unpan1.un.org/intradoc/groups/public/ documents/un/report.pdf

World Economic Forum (2003). The Global Information Technology Report 2002-2003. Readiness for the Networked World. Retrieved October 31, 2018, from Caribbean Elections: http://www.caribbeanelections.com/eDocs/ development_reports/gitr_2002_2003.pdf

World Economic Forum (2004). The Global Information Technology Report 2003-2004. Towards an Equitable Information Society. Retrieved October 30, 2018, from The World Bank: http://documents.worldbank.org/ curated/en/825291468175149560/pdf/343090GITR2003.pdf

World Economic Forum (2005). The Networked Readiness Index Rankings 2005. Retrieved October 31, 2018, from The Internet Archive: https://web.archive.org/web/20120213081759/ 
World Economic Forum (2006). The Global Information Technology Report 2005-2006. Leveraging ICT Advancements for Development. Retrieved October 31, 2018, from UNCTAD: https://unctad.org/sections/wcmu/ docs/c3em29p005_en.pdf

World Economic Forum (2007). The Networked Readiness Index 2006-2007 rankings. The Global Information Technology Report 2006-2007. Retrieved October 31, 2018, from The Internet Archive: https://web.archive.org/ web/20070406180105/

World Economic Forum. (2008). The Networked Readiness Index 2007-2008 rankings. The Global Information Technology Report 2007-2008. Fostering Innovation through Networked Readiness. Retrieved October 30, 2018, from The Internet Archive: https://web.archive.org/web/20080411023235/

World Economic Forum. (2009). The Global Information Technology Report 2008-2009. Mobility in a Networked World. Retrieved October 30, 2018, from The Internet Archive: https://web.archive.org/web/20111027101928/

World Economic Forum. (2010). The Global Information Technology Report 2009-2010. ICT for Sustainability. Retrieved October 30, 2018, from The Internet Archive: https://web.archive.org/web/20110409061000/

World Economic Forum. (2011). The Global Information Technology Report 2010-2011. Transformations 2.0. Retrieved October 30, 2018, from World Economic Forum: http://reports.weforum.org/wp-content/pdf/gitr2011/wef-gitr-2010-2011.pdf

World Economic Forum. (2012). The Global Information Technology Report 2012. Living in a Hyperconnected World. Retrieved October 30, 2018, from World Economic Forum: http://www3.weforum.org/docs/Global_IT_ Report 2012.pdf

World Economic Forum. (2013). The Global Information Technology Report 2013. Growth and Jobs in a Hyperconnected World. Retrieved October 30, 2018, from World Economic Forum: http://www3.weforum.org/ docs/WEF_GITR_Report_2013.pdf

World Economic Forum. (2014). The Global Information Technology Report 2014. Rewards and Risks of Big Data. Retrieved October 30, 2018, from World Economic Forum: http://www3.weforum.org/docs/WEF_ GlobalInformationTechnology_Report_2014.pdf

World Economic Forum. (2015). The Global Information Technology Report 2015. ICTs for Inclusive Growth. Retrieved October 30, 2018, from World Economic Forum: http://www3.weforum.org/docs/WEF_GITR2015.pdf

World Economic Forum. (2016). The Global Information Technology Report 2016. Innovating in the Digital Economy. Retrieved October 30, 2018, from World Economic Forum: http:9/www3.weforum.org/docs/GITR2016/WEF_ GITR_Full_Report.pdf

World Economic Forum. (2016). The Networked Readiness Index Historical Dataset 2012-2016. Retrieved August 13, 2018, from World Economic Forum: http://www3.weforum.org/docs/GITR2016/WEF_NRI_2012-2016_ Historical_Dataset.xlsx

World Wide Web Foundation. (2014). About the Web Index. Retrieved October 30, 2018, from The Web Index: http://thewebindex.org/about/\#about_the_web_index 